\title{
Key factors for successful solving of mathematical word problems in fifth-grade learners
}

\section{BACKGROUND}

Difficulties in solving mathematical word problems (MWP) are one of the most common reasons for weak mathematics performance, and poor mathematical literacy has important implications for an individual's further education, employment opportunities, mental health and quality of life in today's modern technological society.

The purpose of the study was to examine whether Slovenian good and poor MWP solvers differ in arithmetic knowledge and skills, non-verbal reasoning, pupils' self-evaluations of MWP abilities, teachers' assessment of their mathematical knowledge and what strategies fifthgrade learners use in solving MWP.

\section{PARTICIPANTS AND PROCEDURE}

The larger sample included 233 pupils from 14 fifth-grade classes (mean age 10 years 3 months) and 14 teachers. On the basis of the teachers' opinions and the results of MWP solving two sub-samples of 24 students were formed, good and poor MWP solvers. Several tests were used to determine MWP solving ability, automation of arithmetic facts and procedures as well as Raven's SPM. Questionnaires for pupils were used to assess pupils' estimations of MWP tasks' difficulty, their own ability to solve them and the strategies used. To assess pupils' knowledge a questionnaire for teachers was used.

\section{RESULTS}

Slovenian $5^{\text {th }}$ graders in the larger sample generally used very few empirically proven effective cognitive and metacognitive strategies to solve MWP. Pupils with lower achievement in solving MWP, compared to pupils with higher achievement demonstrated significantly less automated arithmetic facts and procedures of the algorithm, less flexible use of arithmetic skills, as well as qualitatively different MWP solving, which is also related to their lower non-verbal reasoning. Teachers' assessments and pupils' self-assessments matched the achieved test results.

\section{CONCLUSIONS}

The results exposed important key factors for successful solving of mathematical word problems with significant implications for learning, teaching and professional training. Improving mathematics literacy in the Slovenian school system requires greater consideration for strategy teaching and motivational factors.

\section{KEY WORDS}

mathematical learning difficulties; mathematical word problems; cognitive and metacognitive strategies 


\section{BACKGROUND}

The importance of mathematical literacy in a technological age is recognized universally. In the Slovenian school system, the presence of learning difficulties in the area of mathematics seriously limits the educational and future employment possibilities of students. Low levels of mathematics literacy in Slovenian learning-disabled (self-reported) adolescents and adults limit the quality of their everyday
Marija Kavkler, Lidija Magajna, Milena Košak Babuder life experiences as well as their educational and vocational possibilities. Thirty-seven percent of adults with self-reported learning disabilities find that their level of arithmetic skills hinders their day-to-day life (handling money, time management, etc.) as well as employability $(11 \%$ in the group of adults with out learning difficulties) (Magajna, Kavkler \& OrtarKrižaj, 2003).

Mathematics is the most frequently negatively graded subject in Slovenia. The mathematics grades in the last three years of primary school have the highest predictive value for success in high school (Flere et al., 2009). The National Assessment of Knowledge which is held at the end of primary school (year 9) revealed that in $201376.7 \%$ of all pupils with special needs (pupils with an intellectual disability are not included) managed to solve less than $50 \%$ of all mathematical tasks, compared to $40.2 \%$ of their peers (National Examinations Centre, 2013). The results of the international PISA 2012 show that $80 \%$ of Slovenian 15-yearolds reach the second level of literacy, which is higher than the OECD average. Twenty percent of secondary school students reach the first and lower than first level of literacy of mathematical literacy, which prevents them from obtaining successful further schooling. Compared with the average of the OECD PISA, Slovenian students (2012, after: Štraus, Šterman Ivančič \& Štigl, 2013) report lower intrinsic motivation for learning mathematics, express more negative beliefs about their abilities at mathematics and, in future, they intend to deal with mathematics to a lesser extent.

In the school-aged population, $5-9 \%$ of pupils have mathematics learning difficulties (MLD) (Geary, 2004; Fuchs et al., 2009; Kavkler, 2011). Mathematics learning difficulties are spread over a continuum from mild and occasional to very expressive and lifelong or from specific to general learning difficulties.

Lerner (1997) notes that pupils with learning difficulties form a very diverse group of students with different cognitive, social, emotional and other features who have significantly greater difficulty in learning than the majority of their peers. According to Sousa (2008), students with MLD are a group of students with general and specific learning difficulties in mathematics who manifest poor performance in mathematics, but do not have intellectual disabilities. The author indicates environmentally induced problems (lack of incentives for learning, bilingualism, poverty, inadequate instruction, etc.) as the cause of learning difficulties, as well as/or learning difficulties arising from a learner's cognitive deficits (poor attention, difficulty with recalling facts and procedures, problems with language processing information, poor working and long-term memory etc.).

\section{MATHEMATICAL WORD PROBLEMS}

Pupils with MLD have deficits that are present in one or more areas. The most frequently mentioned problems appear in the area of conceptual, declarative, procedural and/or problem-solving mathematical knowledge. Pupils with MLD, especially in lower primary school, are more likely than their peers to have difficulties in coping with basic arithmetic skills (Maccini \& Gagnon, 2006; Kavkler, 2011), understanding of algebra (Maccini \& Gagnon, 2006), and with skills to solve mathematical problems (Maccini \& Gagnon, 2006; Passolunghi, 2010; Kavkler, 2011).

Successful solvers of mathematical word problems (MWP) express high intellectual capacity, high numerical skills, a positive attitude towards problem solving, are flexible in their choice of strategies, skip steps in procedures, are able to retrieve more general than specific details of a problem to be solved, etc. (Fleishner, Nazum \& Marzola, 1987). Failure at solving MWP is one of the most common, most difficult and persistent problems in pupils with MLD since it depends on a number of skills, abilities and various knowledge. Conceptual knowledge in relation to the perception of the concept of number and arithmetic operations plays a key role in the successful solving of MWP. Fuchs et al. (2006) presented the cognitive interdependence of the three aspects of mathematical achievements in third grade pupils as follows: 1) retrieval of arithmetic facts; 2) retrieval of processes and algorithms and 3) solving MWP. The author reports that MWP are harder to solve for pupils who have difficulty with basic skills in manipulating numbers, which affects the understanding of numerical relationships, working memory, long-term memory, which is related to less developed language and reading skills, attention and non-verbal problem solving abilities. Desoete and Roeyers (2005) also pointed out that a difference between arithmetic problems and solving MWP exists in added verbal information which requires a pupil to create their own model of a problem. A pupil has to find the missing information from the text, do a calculation and carry out the arithmetic operation as part of an MWP to find the information necessary to successfully solve the problem. Passolunghi (2010) notes that in school MWP problem situations are presented in a verbal way whereas their solutions are obtained by using a series of arithmetic operations, which is why the author suggests that these types of tasks be termed arithme- 
tic word problems. The process of solving such a problem is divided into several stages. There are various cognitive processes within each stage and each process indicates a type of general or specific knowledge which leads to the solution of the problem.

In the research by Dermitzaki, Leonardari and Goudas (2009) effective learning was defined as interaction among cognitive, metacognitive and motivational components. Studies have shown that metacognition is especially important for successful problem solving (De Corte, Greerer \& Verschaffel, 1996; Lucangeli \& Cornoldi, 1997; Montague, 2008). Van der Stel, Veenman, Deelen and Haenen (2010) found that the role of metacognitive skills in mathematics changes with age and they are becoming increasingly important.

Metacognition is involved in almost every aspect of solving MWP, from the initial stages of adequate problem representation to the final stage of interpretation and verification of calculations. Research that is more thorough has been dedicated to the following four metacognitive skills: predicting or goal setting, planning, monitoring, controlling the process of solving and evaluation of the accomplished results (Lucangeli \& Cornoldi, 1997). Sweeney (2010) notes that in contrast to the large number of studies of metacognitive problems (inadequate metacognitive awareness, ineffective strategies, lack of control over their implementation) metacognitive functioning in pupils with specific learning difficulties solving MWP is less studied. The author has studied the differences in metacognitive functioning of learners with specific learning difficulties, pupils with persistent low achievement in mathematics and pupils with average achievement in solving MWP. Compared with relatively limited research in this area focusing mainly on individual components of metacognition, Sweeney has incorporated all three components (metacognitive knowledge, metacognitive experiences and metacognitive strategies), the interrelationship among the three components and the impact of individual components on the actual solving of MWP. Considering the pattern of metacognitive functioning, learners with specific learning difficulties differed from the other two groups. Differences were not significant according to the quantity of metacognitive skills used, but regarding the type and quality of the metacognitive skills. Desoete, Roeyers and De Clercq (2004) found that not all pupils with MLD have the same inadequate cognitive and metacognitive skills and they stressed the need for diagnostic assessment of this field in order to intervene effectively.

Metacognition, or "getting to know our own cognition", the conscious monitoring and control of one's own cognitive processes was divided by Flavell (1987) into metacognitive knowledge, metacognitive skills and metacognitive experiences. Metacognitive experiences include conscious reactions and self-assessment of an individual's performance before, during and after solving tasks, one's beliefs about self-efficacy and self-motivational beliefs that are specific for a particular task. These beliefs are an individual's self-interpretation or self-assessment of their own understanding of a task, one's perception of how difficult a task may be, the level of effort required to complete the task and self-confidence that they are able to solve the task (Efklides, Kourkoulou, Mitsiou \& Ziliaskopoulou, 2006). The research suggests a positive relationship between self-efficacy and cognitive engagement that is the willingness to put in effort and persistence in finding a solution (Hoffman \& Spatariu, 2008; Pintrich \& De Groot, 1990). The more effective the learner feels and the greater his/her confidence to solve a task, the more likely he or she will persevere in solving that task.

In her model of solving MWP, Montague (1992) presented the following seven cognitive and metacognitive processes important for successful problem solving: 1) reading for understanding; 2) paraphrasing by using one's own words and with underlining; 3) visualizing by drawing a schematic representation of a problem; 4) hypothesizing or setting up a plan of solving a problem; 5) estimating or predicting the answer; 6) computing and answering the question of a task; 7) control of planned steps. The model also includes a self-regulative component, the so-called Say, Ask and Check Procedure Model that allows a learner to monitor their own process of solving the problem.

Considering pupils with MLD, their mathematical skills and performance, Montague (1997) emphasized the need to assess the emotional state of a learner especially in relation to educational and social experiences in learning mathematics. Montague found that pupils without MLD in solving the MWP in upper-primary school have a significantly more positive attitude toward mathematics than pupils with MLD. Pupils with MLD consider MWP as much more demanding than their peers without MLD and achieve a significantly lower score, and they spend less time dealing with MWP (they do not read the text carefully, do not make a plan, and do not control processes and results). It is considered, however, that MWP are important for academic success and further professional success.

\section{IDENTIFICATION OF PROBLEMS, HELP AND SUPPORT IN SOLVING MATHEMATICAL WORD PROBLEMS}

Pupils with MLD have weaker performance in solving MWP due to the following: primary causes (a lack of understanding of the problem, difficulty with representation of the problem, cognitive deficits), secondary causes (poor acquisition of arithmetic skills and procedures) and other causes (reading difficulties, emotional, motivational problems) (Geary, 1994). Pupils with
Solving mathematical word problem 
Marija Kavkler,

Lidija Magajna, Milena Košak Babuder
MLD are more likely than their peers to have difficulty determining how to solve a problem: they are not able to plan and carry out a plan to solve a problem (Gagnon \& Maccini, 2008). In solving MWP these learners are less successful because of problems with the following: logical reasoning, complexity and flexibility, planning solutions, checking the results and performing simple arithmetic operations (Adler, 2001).

The causes of problems in solving MWP are therefore varied and multifaceted. To facilitate the identification of pupils with MLD, Stein, Kinder, Silbert and Carnine (2006) advise teachers to divide basic MWP according to: arithmetic operation, numeric volume, the number of steps in the problem (define single and multistep problems), inclusion of irrelevant information (they distract a learner when trying to solve the problem) and the difficulty of the vocabulary which is used to present an MWP as well as the use of complex syntax.

Teachers and special needs teachers have to recognize the difficulties of a learner with MLD to be able to individualize and differentiate requirements in the process of teaching and treatment. In identifying a pupil's problems a teacher must be attentive to: errors in arithmetic fact retrieval (a properly chosen but miscalculated operation), errors in the procedure of algorithms (an appropriate procedure is selected but the execution is incorrect), errors relating to decoding words (connection with misread words), vocabulary errors (they have an impact on understanding the meaning of words, especially on the key ones for the problem), errors associated with the transformation of verbal descriptions in the appropriate mathematical symbols and correct operations, etc. (Stein et al., 2006). Problem solving in MWP is successful if it is not based solely on one character but on an assessment of skills, abilities and the skills needed to solve MWP and to assess the emotional state of a learner in solving the problem (Montague, 1997).

\section{EMPIRICAL PART OF THE RESEARCH}

PURPOSE AND OBJECTIVES OF THE RESEARCH

A number of studies show that deficits in mathematics have been less studied than deficits in reading, and they have a significant impact on the education, employment and daily life of an individual. Management of early mathematical skills is a good predictor of subsequent good or bad educational outcomes of individuals (Clark, Pritchard \& Woodward, 2010; Flere et al., 2009). Low achievement in mathematics is also related to mathematical anxiety. An increase in a learner's competence in the field of mathematics, which is self-evidently an important goal, diminishes the emotional and worry component in mathematics anxiety (Randhawa, Beamer \& Lundberg, 1993). Poor educational outcomes and one's experience of failure in school represent a risk factor for the entire personality development whilst increasing the vulnerability to the influence of other harmful and threatening factors (Tomori et al., 1998). Various ways of preventing school failure through improving mathematical achievements can therefore be included in efforts to protect and promote the mental health of children and adolescents.

The results of national and international research show differences in the achieved levels of mathematical literacy among pupils with MLD and their peers. The level of mathematical literacy significantly depends on the ability to solve MWP, which is why this is the subject of the research.

This study aimed to determine differences between good and poor MWP solvers considering arithmetic skills and knowledge, abilities of non-verbal reasoning, choice of cognitive and metacognitive strategies to solve MWP, teachers' assessments of pupils' mathematical knowledge and pupils' assessments of level of difficulty and strategies to solve MWP.

\section{HYPOTHESIS AND RESEARCH QUESTION}

H1: There are statistically significant differences in arithmetic skills and abilities of non-verbal reasoning between good and poor MWP solvers.

H2: There are differences in teachers' ratings of good and poor problem solvers' arithmetic skills and abilities to solve MWP.

H3: Good and poor problem solvers differ in their estimates of tasks difficulty and their own ability of solving MWP.

Research question:

R1. What strategies do fifth-grade learners use in solving MWP?

\section{PARTICIPANTS AND PROCEDURE}

The larger sample included 233 pupils of 14 entire $5^{\text {th }}$ grade classes. At the time of testing the average age of the pupils was 10 years and 3 months. Pupils attended one of the $5^{\text {th }}$ grade classes. On the basis of teachers' evaluations and the results of the Word problems test (Passolunghi \& Bizzaro, 2011), two sub-samples were selected (24 poor and 24 good MWP solvers, the former scoring 0-3 points and the latter scoring 6-9 points in solving MWP). The research sample also included 14 teachers. Psychologists tested the high and low achieving subsamples with Standard Progressive Matrices (SPM).

\section{INSTRUMENTS}

The following measurement instruments were used in the research: 
Teachers' Questionnaire on Pupils' Arithmetic Knowledge (Passolunghi, Kavkler, Košak Babuder \& Magajna, 2011) included four questions to assess knowledge of arithmetic (arithmetic knowledge in general and multiplication table retrieval) and MWP (simple and complex). Teachers rated the arithmetic skills of every pupil from the sample on a scale of 1 (very successful) to 5 (very unsuccessful).

All pupils solved:

Word Problem Test (Passolunghi \& Bizzaro, 2011), which includes 9 mathematical word problems, three of which are simple while others are more complex. The MWP are short and include a real-life context. The study included a variable score/number of points (0-14 points).

10-minute Test for Assessing Automation of Arithmetic Facts and Procedures (Tancig, Magajna \& Kavkler, 1999), which includes 62 calculations that are evaluated with 1 point (easy) to 3 points (composed of various arithmetic operations). The sum of all possible points is 117 . The study included a variable score/number of points (ranging from 27 to 117$)$.

5-minute test, calculations to obtain a given result (Tancig, Magajna \& Kavkler, 1999), which measured the ability of flexible use of arithmetic knowledge. Calculations were ranked by 1 point (only operation of addition or multiplication is used), 2 points (operation of subtraction or division is used) or 3 points (two or more arithmetic operations are used). The study included a variable score/number of points (0 to 77 points).

Children's Questionnaire on the Evaluation of Task Difficulty, Mathematical Word Problem Solving Ability and Strategies (Passolunghi, Kavkler, Košak Babuder \& Magajna, 2011) was created for the purpose of the research. The questionnaire includes eight tasks. In five tasks pupils estimate the level of difficulty of a given MWP and assess their own abilities in solving these tasks whereas in three questions pupils present their strategies for solving MWP. The questionnaire aimed to highlight both knowledge and mastery of cognitive strategies of both good and poor MWP solvers as well as their perception of their own competence and the difficulty of solving the given word problems. Metacognitive knowledge which includes knowledge and assessment of one's own abilities as well as the requirements of tasks and the management of cognitive and metacognitive strategies is strongly related to understanding and motivation.

Pupils from the subgroup of poor $(N=24)$ and good MWP solvers $(N=24)$ were tested on Standard Progressive Matrices (Raven et al., 2005) that assess nonverbal intelligence, thus allowing for a more accurate comparison between the two groups. Standard Progressive Matrices measure components of general intelligence, especially the ability to form non-verbal concepts and reasoning.

\section{STATISTICAL DATA PROCESSING}

The results obtained with the selected measurement instruments are presented with methods of descriptive statistics. Differences between the subgroups of pupils are tested using a $t$-test. Information about the (metacognitive) attitudes towards solving MWP is presented in tables and analyzed qualitatively.

\section{RESULTS AND DISCUSSION}

\section{RESULTS OF WORD PROBLEMS, STANDARD PROGRESSIVE MATRICES AND ARITHMETIC TESTS OF PUPILS' SAMPLE}

Table 1 shows estimates of the basic parameters of descriptive statistics of the variables of individual tests for the group of poor MWP solvers and the group of good MWP solvers.

\section{RESULTS OF ARITHMETIC TESTS AND STANDARD PROGRESSIVE MATRICES AMONG POOR AND GOOD MATHEMATICAL WORD PROBLEM SOLVERS}

The results in Table 2 show that good MWP solvers demonstrate significantly higher non-verbal reasoning abilities and achieve better results in the field of automation of arithmetic facts and operations in the algorithm, compared to poor MWP solvers. There are statistically significant differences between the group of poor MWP solvers and the group of poor MWP solvers considering their ability to use flexible arithmetic skills. The results indicate greater variability in the field of automation of arithmetic facts and operations in the algorithm in the group of good solvers, while the variability in the ability of flexible use of arithmetic knowledge is greater in the group of good solvers. From this we can conclude that those pupils who have automated the arithmetic facts and procedures of the algorithm but have not mastered the other necessary cognitive and metacognitive strategies cope with difficulties in solving MWP. In the group of pupils with higher scores at solving MWP there are also pupils who cannot use their arithmetic skills flexibly.

In the subsample of poor MWP solvers pupils have greater difficulties when trying to recall arithmetic facts and procedures, and significantly greater difficulty in solving mathematical reasoning and solving MWP than their peers who are successful in the end. The results of pupils with MLD are in accordance with the description of level one mathematical litera-
Solving mathematical word problem 
Table 1

Descriptive statistics of variables of individual tests between a group of good and group of poor mathematical word problems solvers

\begin{tabular}{cccccc}
\hline Variable & $\begin{array}{c}\text { Group } \\
\text { (1-poor, 2-good })\end{array}$ & $N$ & $M$ & SD & $\begin{array}{c}\text { Stand. error } \\
\text { of the } M\end{array}$ \\
\hline 10-min test - weighted scores & 1 & 24 & 56.5417 & 16.1110 & 3.2886 \\
5-min test - weighted scores & 2 & 24 & 103.7083 & 12.4149 & 2.5342 \\
Raven SPM - raw scores & 1 & 24 & 12.0000 & 8.8955 & 1.8158 \\
& 2 & 24 & 33.9167 & 18.0529 & 3.6850 \\
MWP - weighted scores & 1 & 24 & 33.42 & 5.85 & 1.19 \\
& 2 & 24 & 42.21 & 7.80 & 1.59 \\
\hline
\end{tabular}

Note. Group 1 - poor - poor MWP solvers; group 2 - good - good MWP solvers; $N$ - number; $S D$ - standard deviation; $M=$ arithmetic mean

Table 2

Testing homogeneity of variance and t-test to test the variability of the group of good and the group of poor mathematical word problem solvers

\begin{tabular}{|c|c|c|c|c|c|c|}
\hline \multirow[t]{2}{*}{ Variable } & & \multicolumn{2}{|c|}{$\begin{array}{l}\text { Levene's test } \\
\text { for equality } \\
\text { of variances }\end{array}$} & \multirow{2}{*}{$\begin{array}{l}T \text {-test } \\
\text { for } \\
\text { equality } \\
\text { of means }\end{array}$} & \multirow[t]{2}{*}{$d f$} & \multirow[t]{2}{*}{$\begin{array}{c}\text { Sig. } \\
\text { (2-tailed) }\end{array}$} \\
\hline & & $F$ & Sig. & & & \\
\hline \multirow{2}{*}{$\begin{array}{c}10-\text { min test } \\
\text { - weighted scores }\end{array}$} & Equal variances assumed & 3.903 & 0.054 & -11.361 & 46 & 0.000 \\
\hline & Equal variances not assumed & & & -11.361 & 43.194 & 0.000 \\
\hline \multirow{2}{*}{$\begin{array}{c}\text { 5-min test } \\
\text { - weighted scores }\end{array}$} & Equal variances assumed & 5.041 & 0.030 & -5.335 & 46 & 0.000 \\
\hline & Equal variances not assumed & & & -5.335 & 33.547 & 0.000 \\
\hline \multirow{2}{*}{$\begin{array}{l}\text { Raven SPM } \\
\text { - raw scores }\end{array}$} & Equal variances assumed & 2.364 & 0.131 & -4.416 & 46 & 0.000 \\
\hline & Equal variances not assumed & & & -4.416 & 42.660 & 0.000 \\
\hline \multirow{2}{*}{$\begin{array}{c}\text { MWP } \\
\text { - weighted scores }\end{array}$} & Equal variances assumed & 2.792 & 0.102 & -15.117 & 46 & 0.000 \\
\hline & Equal variances not assumed & & & -15.117 & 43.730 & 0.000 \\
\hline
\end{tabular}

cy as presented in OECD-PISA 2009 research (2011). These pupils succeed only in solving tasks with simple and clear questions related to known contexts by using routine procedures. They can successfully execute procedures that are obvious and follow immediately from the given text. The results show that both good and poor problem solvers need training in the flexible use of arithmetic skills. To cope successfully with MWP important cognitive and metacognitive strategies are required. Metacognition allows students to apply the acquired knowledge in a flexible, strategic manner (Lucangeli, Cornoldi \& Tellarini, 1998; Montague, 2008). A more detailed analysis of the metacognitive skills, in particular, observing the use of metacognitive skills recommended by Desoete et al. (2004), could shed more light on barriers to the flexible use of arithmetical skills and enable more effective suggestions for teaching and reading.

\section{TEACHERS' RATINGS OF GOOD AND POOR PROBLEM SOLVERS' ARITHMETIC SKILLS AND ABILITIES TO SOLVE MATHEMATICAL WORD PROBLEMS}

The data in Table 3 demonstrate great differences in teachers' ratings of good and poor problem solvers' arithmetic skills and abilities to solve MWP. Slovenian teachers are good at evaluating the mathematical abilities and skills of pupils with difficulties in solving MWP and those who are good MWP solvers. The data are consistent with previously presented test results. Teachers are successful in assessing the 
Table 3

Descriptive statistics of variables based on Teachers' Questionnaire by subgroups of pupils

\begin{tabular}{|c|c|c|c|}
\hline \multirow[t]{2}{*}{ Variable } & \multirow[t]{2}{*}{ Category } & \multicolumn{2}{|c|}{$\%$ of pupils } \\
\hline & & $\begin{array}{c}\text { group } 1 \\
\text { (poor } \mathrm{MWP} \text { solvers) }\end{array}$ & $\begin{array}{c}\text { group } 2 \\
(\operatorname{good} M W P \text { solvers) }\end{array}$ \\
\hline \multirow{5}{*}{$\begin{array}{l}\text { How successfully does } \\
\text { a pupil solve } 4 \text { basic } \\
\text { arithmetic operations? }\end{array}$} & 1 - very successful & 4.2 & 95.8 \\
\hline & 2 & 16.7 & 4.2 \\
\hline & 3 & 54.2 & 0 \\
\hline & 4 & 20.8 & 0 \\
\hline & 5 - very unsuccessful & 4.2 & 0 \\
\hline \multirow{5}{*}{$\begin{array}{l}\text { How successful is } \\
\text { a pupil at retrieving } \\
\text { multiplication tables? }\end{array}$} & 1 - very successful & 0 & 100.0 \\
\hline & 2 & 29.2 & 0 \\
\hline & 3 & 41.7 & 0 \\
\hline & 4 & 29.2 & 0 \\
\hline & 5 - very unsuccessful & 0 & 0 \\
\hline \multirow{5}{*}{$\begin{array}{c}\text { How successful is } \\
\text { a pupil at solving } \\
\text { simple MWP (with one } \\
\text { arithmetic operation)? }\end{array}$} & 1 - very successful & 0 & 95.8 \\
\hline & 2 & 8.3 & 4.2 \\
\hline & 3 & 50.0 & 0 \\
\hline & 4 & 37.5 & 0 \\
\hline & 5 - very unsuccessful & 4.2 & 0 \\
\hline \multirow{5}{*}{$\begin{array}{l}\text { How successful is } \\
\text { a pupil at solving } \\
\text { MWP with two or } \\
\text { more arithmetic } \\
\text { operations? }\end{array}$} & 1 - very successful & 0 & 62.5 \\
\hline & 2 & 0 & 37.5 \\
\hline & 3 & 16.7 & 0 \\
\hline & 4 & 50.0 & 0 \\
\hline & 5 - very unsuccessful & 33.3 & 0 \\
\hline
\end{tabular}

performance of retrieval of arithmetic facts, procedural control knowledge and skills to solve various complex MWP. They are attentive to various areas of mathematical achievements, which enables them to detect pupils with MLD more effectively.

The next step in the process of effective instruction of mathematics has to be greater individualization and differentiation of requirements for pupils with MLD. Intensive instruction methods should include more intensive instruction in the areas of weakness (automation, cognitive, metacognitive strategies and their flexible use).

\section{DIFFERENCES IN THE ESTIMATES OF TASK DIFFICULTY AND MATHEMATICAL WORD PROBLEM-SOLVING SKILLS AMONG POOR MATHEMATICAL WORD PROBLEM SOLVERS AND GOOD MATHEMATICAL WORD PROBLEM SOLVERS}

Some interesting differences in attitudes to MWP solving are noted. From the pupils' responses in Ta- ble 4 to the question How much do you like solving $M W P$ ? we can see a huge difference in selecting the categories very much and I like between poor MWP solvers (29.1\%) and good MWP solvers (70.8\%).

A great difference between good and poor MWP solvers is present also in their assessments of the level of difficulty of MWP problems and their beliefs as regards to their own ability to solve the tasks. The results of the pupils' subjective appraisals of task difficulty and their problem solving ability in Table 4 correspond to the results on the MWP test achieved by good and poor MWP solvers in Table 1.

A realistic self-assessment portrait of Slovenian pupils, both poor and good solvers considering solving MWP, is manifested as it is consistent with the actual achievements obtained by the test. These differences would be useful to explore further, since motivation, interest in solving MWP and the ability to assess the level of a task's difficulty have a great impact on a pupil's further engagement in or avoidance of such activities. There may be more reasons for the differences noted - for example, an unpleasant experience of failure at activities that are too
Solving mathematical word problem 
Marija Kavkler, Lidija Magajna, Milena Košak Babuder
Table 4

Descriptive statistics of variables in the Children's Questionnaire on the evaluation of level of difficulty, learner's ability and mathematical word problem strategies

\begin{tabular}{|c|c|c|c|}
\hline \multirow{2}{*}{ Variable } & \multirow{2}{*}{ Category } & \multicolumn{2}{|c|}{$\%$ of pupils } \\
\hline & & group 1 (poor solvers) & group 2 (good solvers) \\
\hline \multirow{5}{*}{$\begin{array}{c}\text { How much does } \\
\text { a pupil like solving MWP? }\end{array}$} & 1 - very much & 8.3 & 33.3 \\
\hline & 2 & 20.8 & 37.5 \\
\hline & 3 & 37.5 & 25.0 \\
\hline & 4 & 29.2 & 0 \\
\hline & 5 - don't like at all & 4.2 & 4.2 \\
\hline \multirow{5}{*}{$\begin{array}{l}\text { How difficult is it for } \\
\text { a pupil to solve MWP? }\end{array}$} & 1 - very easy & 0 & 33.3 \\
\hline & 2 - easy & 20.8 & 29.2 \\
\hline & 3 - medium & 58.3 & 37.5 \\
\hline & 4 - difficult & 12.5 & 0 \\
\hline & 5 - very difficult & 8.3 & 0 \\
\hline \multirow{5}{*}{$\begin{array}{l}\text { Pupil's assessment of the } \\
\text { level of difficulty of MWP } 1 \\
\text { (only one mathematical } \\
\text { operation is needed } \\
\text { to solve it) }\end{array}$} & 1 - very easy & 12.5 & 41.7 \\
\hline & 2 - easy & 25 & 45.8 \\
\hline & $3-$ medium & 54.2 & 8.3 \\
\hline & 4 - difficult & 0 & 4.2 \\
\hline & 5 - very difficult & 8.3 & 0 \\
\hline \multirow{5}{*}{$\begin{array}{l}\text { Pupil's belief about their } \\
\text { own ability to solve MWP } 1\end{array}$} & 1 - very strong & 4.3 & 45.8 \\
\hline & 2 & 13.0 & 37.5 \\
\hline & 3 & 47.8 & 8.3 \\
\hline & 4 & 17.4 & 4.2 \\
\hline & $5-$ I'm not sure & 17.4 & 4.2 \\
\hline \multirow{5}{*}{$\begin{array}{l}\text { Pupil's assessment of the } \\
\text { level of difficulty of MWP } 2 \\
\text { (two mathematical } \\
\text { operations are } \\
\text { needed to solve it) }\end{array}$} & 1 - very easy & 12.5 & 70.8 \\
\hline & 2 - easy & 12.5 & 25.0 \\
\hline & 3 - medium & 58.3 & 42 \\
\hline & 4 - difficult & 4.2 & 0 \\
\hline & 5 - very difficult & 12.5 & 0 \\
\hline \multirow{5}{*}{$\begin{array}{l}\text { Pupil's belief about their } \\
\text { own ability to solve MWP } 2\end{array}$} & 1 - very strong & 8.7 & 54.2 \\
\hline & 2 & 17.4 & 25.0 \\
\hline & 3 & 43.5 & 12.5 \\
\hline & 4 & 17.4 & 8.3 \\
\hline & $5-$ I'm not sure & 13.0 & 0 \\
\hline \multirow{5}{*}{$\begin{array}{c}\text { Pupil's assessment } \\
\text { of the level } \\
\text { of difficulty of MWP } 3 \text { (three } \\
\text { mathematical operations } \\
\text { are needed to solve it) }\end{array}$} & 1 - very easy & 8.3 & 33.3 \\
\hline & 2 - easy & 16.7 & 54.2 \\
\hline & $3-$ medium & 37.5 & 12.5 \\
\hline & 4 - difficult & 29.2 & 0 \\
\hline & 5 - very difficult & 8.3 & 0 \\
\hline \multirow{5}{*}{$\begin{array}{l}\text { Pupil's belief about their } \\
\text { own ability to solve MWP } 3\end{array}$} & 1 - very strong & 12.5 & 54.2 \\
\hline & 2 & 167 & 33.3 \\
\hline & 3 & 41.7 & 8.3 \\
\hline & 4 & 20.8 & 4.2 \\
\hline & 5 - I'm not sure & 8.3 & 0 \\
\hline
\end{tabular}


Table 5

Frequency and proportions of selected steps to solve mathematical word problem (MWP) of pupils from the total sample

\begin{tabular}{lcc}
\hline \multicolumn{1}{c}{$\begin{array}{c}\text { Model of seven cognitive strategies of solving MWP } \\
\text { (Montague, 1992, in: Montague \& Dietez, 2009) }\end{array}$} & $\begin{array}{c}\text { Number } \\
\text { of pupils }\end{array}$ & of pupils \\
\hline (0) without a strategy to solve an MWP & 34 & 6.5 \\
(1) read the problem & 162 & 30.7 \\
(2) find and underline the data & 74 & 14.0 \\
(3) illustrate & 4 & 0.8 \\
(4) determine what the problem is and provide calculating steps & 27 & 5.1 \\
(5) evaluate the outcome & 44 & 8.3 \\
(6) compute and answer & 182 & 34.5 \\
(7) check & 0 & 0.0 \\
\hline
\end{tabular}

complex for an individual; or generally poor learning self-esteem and an excessively critical assessment of one's own abilities, etc. In this respect, a number of issues arise related to the influence of self-efficacy on further motivation to learn mathematics, which is low in Slovenian pupils (PISA 2012, after: Štraus et al., 2013), and persistence in overcoming problems. The sense of self-efficacy: which is associated with the mastery of effective strategies, helps an individual to gradually progress also in the case when the initial knowledge is weak. The present ways of teaching do not develop self-efficacy, they hinder the development of the ability to cope and overcome difficulties, since a pupil is not motivated to persevere and further invest in training strategies. In this respect, excessive self-criticism of poor solvers, in perceiving MWP as very difficult, can be less favorable for their further development and may lead to the development of 'learned helplessness', instead of the development of resiliency.

\section{STRATEGIES FOR SOLVING MATHEMATICAL WORD PROBLEMS REPORTED BY FIFTH-GRADE LEARNERS}

Pupils in the larger sample $(N=233)$ reported strategies that are suitable for solving the MWP below. It was possible to report several strategies. Students had to write down autonomously the steps to solve the MWP with no given list of strategies (what should be done before and after), but they did not actually solve the task itself.

Word problem: Before he began to deliver newspapers, a newspaper delivery boy had 157 newspapers. He delivered 38 newspapers in the first street, and twice as many in the second one. How many newspapers has he still got?

Table 5 shows that 233 pupils of the total sample of $5^{\text {th }}$ grade pupils most frequently report that in tackling the above MWP strategy they use calculate and answer (34.5\%) and read strategies (30.7\%). Some of the pupils (6.5\%) were not able to design steps to solve MWP, and did not indicate any possible solving strategies. The finding that no pupils mentioned the step associated with the evaluation process of the assignment is a cause for concern. Also, only $0.8 \%$ of pupils stated that they illustrate the task and 5.1\% of pupils predict problem solving steps of the MWP.

Fifth-grade pupils are apparently unaware of successful solving strategies of MWP as they indicate few cognitive and metacognitive strategies that have a significant impact on the performance of MWP (Lucangeli et al., 1998; Adler, 2001; Dermitzki et al., 2009; Montague, 1992; Montague \& Dietz, 2009; Dawson, 2010).

Since the results of the whole sample are presented, a greater need to include the teaching of metacognitive skills and strategies that require direct teaching methods and appropriate training of teachers is suggested. The results of various studies (Sweeney, 2010) show that not only the amount of metacognitive skills matters, but so do the type and quality of such skills. Although a pupil may have some metacognitive knowledge relating to solving MWP, it does not mean that they are able to use this knowledge during the actual solving of MWP.

\section{CONCLUSIONS}

The research results highlight both strong and weak areas of knowledge and skills to solve MWP as well as the need to improve instruction, treatment and training of professionals to teach and address the specific strategies to solve MWP and exercise their use.

The results of the survey show that poor MWP solvers express significantly less automated arithmetic facts and procedures of the algorithm, are less flexible in the use of arithmetic knowledge and less effec-
Solving mathematical word problem 
Marija Kavkler,

Lidija Magajna, Milena Košak Babuder tively address MWP than good MWP solvers, which is partly also due to their lower level of non-verbal reasoning abilities. Knowledge of poor MWP solvers is fairly consistent with the one described as Level 1 of mathematical literacy, which is defined in the documents of the OECD-PISA 2009 (2011) research.

Many authors (Fuchs et al., 2006; Stein et al., 2006; Fletcher, Lyon, Fuchs \& Barnes, 2007; Kavkler, 2011) associate the automation of arithmetic facts and procedures and algorithms with overall performance in mathematics, including solving MWP, which is especially evident in pupils with MLD. Passolunghi (2010) however points out that even pupils who express well-automated facts and procedures may have difficulty in solving MWP, as is evident from the results of the pupils involved in the full sample of our study.

In various sources some authors (Lucangeli et al., 1998; Dermitzki et al., 2009; Montague, 1992; Montague \& Dietz, 2009; Dawson, 2010) emphasize the importance of cognitive and metacognitive strategies for successful solving of MWP: therefore the pupils involved in the research filled in the questionnaire which was used to assess their metacognitive and cognitive skills to solve MWP. From the obtained results it is evident that Slovenian fifth-grade learners lack awareness of the use of cognitive and metacognitive strategies for solving MWP.

From teachers' assessments of the performance of each student in relation to the management of the four basic arithmetic operations, recall of multiplication and solving simple and complex MWP, it is evident that most teachers assess students in accordance with their achievements. It is however obvious that the teachers provide feedback to pupils in a manner that does not encourage motivation and does not support individual beliefs about their own chances of improvement in mathematics which would equip a student with MLD with a sense of competence rather than frustration. Slovenian students compared with the average of the OECD PISA 2012 reported lower intrinsic motivation for learning mathematics, express more negative beliefs about their abilities in mathematics and intend to deal with mathematics in future to a lesser extent (Štraus et al., 2013).

In any case, the results indicate that it is necessary to pay greater attention to strategies to motivate students for a more realistic appraisal of task difficulty and experience more difficult tasks that require a certain level of investment of effort as a challenge, not as another possibility of failure. The sense of self-efficacy is very important for pupils' further engagement and progress, even more than self-esteem, and it depends on the mastery of effective strategies that enable the individual to gradually progress despite weak initial knowledge or skills. Teachers and other educators, and pupils with MLD will require various forms of assistance in the future and greater attention will be paid to the development of effective strat- egies to solve MWP, which will result in an improved sense of self-efficacy.

\section{References}

Adler, B. (2001). What is dyscalculia? An e-book from the Kognitive Centrum Sweden. Retrieved: June 12, 2006, from www.dyscalculiainfo.org.

Clark, C.A.C., Pritchard, V.E. \& Woodward, L.J. (2010). Preschool executive functioning abilities predict early mathematics achievement. Development Psychology, 46, 1176-1191.

Dawson, P. (2010). Lazy or not? Educational Leadership, 68, 35-38.

Dermitzaki, I., Leonardari, A. \& Goudas, M. (2009). Relations between young students' strategic behaviours, domain-specific self concept, and performance in a problem-solving situation. Learning and Instruction, 19, 144-157.

Desoete, A., Roeyers, H. \& De Clercq, A. (2004). Children with mathematics learning disabilities in Belgium. Journal of Learning Disabilities, 37, 50-61.

Desoete, A. \& Roeyers, H. (2005). Cognitive building blocks in mathematical problem solving in grade 3. British Journal of Educational Psychology, 75, 119138.

De Corte, E., Greer, B. \& Verschaffel, L. (1996). Mathematics teaching and learning. In: D. Berliner \& R. Calfee (eds.). Handbook of educational psychology. New York: Macmillan.

Efklides, A., Kourkoulou, A., Mitsiou, F. \& Ziliaskopoulou, D. (2006). Effort regulation, effort perceptions, mood, and metacognitive experiences: What determines the estimate of effort expenditure? Metacognition and Learning, 1, 33-49.

Flavell, J. (1987). Speculations about the nature and development of metacognition. In: F.E. Weinert \& R.H. Kluwe (eds.). Metacognition, motivation and understanding (pp. 21-29). Hillsdale, NJ: Lawrence Erlbaum.

Flere, S., Klanjšek, R., Musil, B., Tavčar Krajnc, M. \& Kirbiš, A. (2009). Kdo je uspešen v slovenski šoli? Znanstveno poročilo [Who is successful in the Slovene school? Scientific report]. Ljubljana: Pedagoški inštitut.

Fleischner, J.E., Nuzum, M.B. \& Marzola, E.S. (1987). Devising an instructional program to teach arithmetic problem-solving skills to students with learning disabilities. Journal of Learning Disabilities, 20, 214-217.

Fletcher, J.M., Lyon, G.R., Fuchs, L.S. \& Barnes, M.A. (2007). Learning disabilities: From identification to intervention. New York: The Guilford Press.

Fuchs, L.S., Fuchs, D., Compton, D.L., Powell, S.R., Seethaler, P.M., Capizzi, A.M., Schatschneider, C. \& Fletcher, J.M. (2006). The cognitive correlates of third-grade skill in arithmetic, algorithmic com- 
putation and arithmetic word problems. Journal of Educational Psychology, 98, 29-43.

Fuchs, L.S., Powell, S.R., Seethaler, P.M., Cirino, P.T., Fletcher, J.M., Fuchs, D., Hamlett, C.L. \& Zumeta, R.O. (2009). Remediating number combination and word problem deficits among students with mathematics difficulties: A randomized control trial. Journal of Educational Psychology, 101, 561576.

Gagnon, J. \& Maccini, P. (2008). S.T.A.R. Strategy for Problem Solving. Retrieved: March 8, 2010, from http://www.k8accesscenter.org.training_resources/documents/. MathSIforMiddleschoolStudentswithLD.pdf.

Geary, D.C. (1994). Children's Mathematical Development. Research and Practical Applications. Washington: American Psychological Association.

Geary, D.C. (2004). Mathematics and learning disabilities. Journal of Learning Disabilities, 37, 4-15.

Hoffman, B. \& Spatariu, A. (2008). The influence of self-efficacy and metacognitive prompting on math problem-solving efficiency. Contemporary Educational Psychology, 33, 875-893.

Kavkler, M. (2011). Učenci z učnimi težavami pri matematiki - učinkovitejše odkrivanje in diagnostično ocenjevanje. In: L. Magajna \& M. Velikonja (eds.). Učenci z učnimi težavami. Prepoznavanje in diagnostično ocenjevanje [Students with learning difficulties. Identification and diagnostic assessment] (pp. 130-146). Ljubljana: Faculty of Education.

Lerner, J. (1997). Learning disabilities: Theories, diagnosis, and teaching strategies. $7^{\text {th }}$ ed. New York: Houghton Mifflin Company.

Lucangeli, D. \& Cornoldi, C. (1997). Mathematics and metacognition: what is the nature of the relationship? Mathematical Cognition, 3, 121-139.

Lucangeli, D., Cornoldi, C. \& Tellarini, M. (1998). Metacognition and learning disabilities in mathematics. In: T.E. Scruggs, M.A. Mastropieri (eds.). Advances in Learning and Behavioral Disabilities (pp. 219-244). Greenwich, CT: JAI Press.

Maccini, P. \& Gagnon, J. (2006). Mathematics strategy instruction (SI) for middle school students with learning disabilities. Retrieved April 21, 2011, from www.k8accesscenter.org.

Magajna, L., Kavkler, M. \& Ortar-Križaj, M. (2003). Adults with self-reported learning disabilities in Slovenia: findings from the international adult literacy survey on the incidence and correlates of learning disabilities in Slovenia. Dyslexia, 9, 229251.

Montague, M. (1992). The effects of cognitive and metacognitive strategy instruction on the mathematical problem solving of middle school students with learning disabilities. Journal of Learning Disabilities, 25, 230-248.
Montague, M. (1997). Students' perception, mathematical problem solving, and learning disabilities. Remedial and Special Education, 28, 46-53.

Montague, M. (2008). Self-regulation strategies to improve mathematical problem solving for students with learning disabilities. Learning Disability Quarterly, 31, 37-44.

Montague, M. \& Dietez, S. (2009). Evaluating the evidence base for cognitive strategy instruction and mathematical problem solving. Exceptional Children, 75, 285-302.

National Examination Centre (2013). Nacionalno preverjanje znanja: Letno poročilo o izvedbi v letu 2012/2013 [National assessment of knowledge: Annual Report for the year 2012/2013].

OECD-PISA 2009 (2011). Program mednarodne primerjave dosežkov učencev - Prvi rezultati. Preverjanje in cenjevanje, 8, 61-96.

Passolunghi, M.C. (2010). Učne težave pri matematiki. Specifične učne težave $v$ vseh obdobjih. Tretja mednarodna konferenca o specifičnih učnih težavah $v$ Sloveniji in nacionalna konferenca Tempus-Isheds. Zbornik prispevkov [Learning difficulties in math. Specific learning difficulties in all periods. The $3^{\text {rd }}$ International Conference on specific learning difficulties in Slovenia and the National Conference of the Tempus-Isheds. Book of articles] (pp. 1421). Ljubljana: Bravo, društvo za pomoč otrokom in mladostnikom s specifičnimi učnimi težavami.

Passolunghi, M.C. \& Bizzaro, M. (2011). Preparasi ai problemi aritmetici di scuola secondaria (Prepare for the arithmetic problems of secondary school). Trento: Erickson.

Passolunghi, M.C., Kavkler, M., Košak Babuder, M. \& Magajna, M. (2011). Children's Questionnaire on math word problems strategies. Trieste: Faculty of Psychology.

Pintrich, P.R. \& De Groot, E. (1990). Motivational and self-regulated learning components of classroom academic performance. Journal of Educational Psychology, 82, 33-50.

Randhawa, B.S., Beamer, J.E. \& Lundberg, I. (1993). Role of mathematics self-efficacy in the structural model of mathematical achievement. Journal of Educational Psychology, 85, 41-48.

Raven, J.C., Raven, M., Styles, I., Raven, J. \& Court, J.H. (2005). Priročnik Standardne progresivne matrice, 3. zvezek [Manual for Standard Progressive Matrices. 3 Volume]. Ljubljana: Center za psihodiagnostična sredstva.

Sousa, D.A. (2008). Recognizing and addressing mathematics difficulties. How the brain learns mathematics (pp. 163-198). London: Corwin Press Ltd. A SAGE Publications Company.

Stein, M., Kinder, D., Silbert, J. \& Carnine, D.W. (2006). Designing effective mathematics instruction. $A$ direct instruction approach. $4^{\text {th }}$ ed. New Jersey: Person Education, Inc.
Solving mathematical word problem 
Marija Kavkler, Lidija Magajna, Milena Košak Babuder
Sweeney, C.M. (2010). The metacognitive functioning of middle school students with and without learning disabilities during mathematical problem solving. Open Access Dissertations. Paper 433.

Štraus, M., Šterman Ivančič, K. \& Štigl, S. (2013). OECD PISA 2012: matematični, bralni in naravoslovni dosežki slovenskih učencev: program mednarodne primerjave dosežkov učencev 2012: nacionalno poročilo [OECD PISA 2012: math, reading and science achievements of Slovenian students: international comparisons of students' 2012: National report]. Ljubljana: Pedagoški Inštitut.

Tancig, S., Magajna, L. \& Kavkler, M. (1999). The development of numeracy in Slovenia. In: Abstracts: biennial meeting. Göteborg: European Association for Research on Learning and Instruction (EARLI).

Tomori, M., Stergar, E., Pinter, B., Rus Makovec, M. \& Stikovič, S. (1998). Dejavniki tveganja pri slovenskih srednješolcih [Risk factors in Slovenian secondary school students]. Ljubljana: Psihiatrična klinika.

Van der Stel, M., Veenman, M.V.J., Deelen, K. \& Haenen, J. (2010). Increasing role of metacognitive skills in math: a cross-sectional study from a developmental perspective. ZDM International Journal on Mathematics Education, 42, 219-229. 